\title{
Disparities in the Wage-and-Salary Earnings, Determinants, and Distribution of Health Economics, Outcomes Research, and Market Access Professionals: An Exploratory Study
}

\author{
Ioana Popovici ${ }^{1} \cdot$ Manuel J. Carvajal $^{1}$ (D) $\cdot$ Patti Peeples $^{2} \cdot$ Silvia E. Rabionet $^{1,3}$
}

Accepted: 10 December 2020 / Published online: 11 January 2021

(c) The Author(s) 2021

\begin{abstract}
Objective The aim was to estimate the wage-and-salary earnings of a sample of health economics, outcomes research, and market access (HE/OR/MA) professionals; compare male versus female and US versus non-US earnings; assess the magnitude of the effect of several human-capital and job-related covariates on the determination of earnings; and examine inequality in the distribution of earnings.

Methods The study used self-reported survey data collected in 2017 from a subset of HE/OR/MA professionals in the HealthEconomics.com global subscriber list. HE/OR/MA professionals in this subset completed a questionnaire. The sample consisted of 372 participants who reported their wage-and-salary earnings and other indicators. The sample was not necessarily representative of the global HE/OR/MA community. The study methods included a two-way classification model with multiple replications, an ordinary least-squares model, and three inequality indicators.

Principal Findings The results suggested substantial disparities between the wage-and-salary earnings of respondents living in the USA and those living in other countries; mild gender disparities in earnings; greater inequality outside the USA than within the USA; and, within each location, more unequal distribution of men's earnings than that of women's earnings. Conclusions Although the findings may not be extrapolated to the worldwide population of HE/OR/MA professionals, they provide a point of comparison with earlier studies and offer insights into the mechanics of one of the most innovative and fastest growing health-sector workforce segments in developed as well as emerging countries.
\end{abstract}

Manuel J. Carvajal

cmanuel@nova.edu

Ioana Popovici

Ioana.Popovici@nova.edu

Patti Peeples

patti@healtheconomics.com

Silvia E. Rabionet

rabionet@nova.edu

1 Department of Sociobehavioral and Administrative Pharmacy, College of Pharmacy, Nova Southeastern University, 3200 South University Drive, Fort Lauderdale, FL 33328-2018, USA

2 HE Institute, HealthEconomics.com, 1327 Walnut Street, Jacksonville 32206, FL, USA

3 University of Puerto Rico, Medical Sciences Campus, P.O. Box 365067, San Juan 00936-5067, Puerto Rico, USA

\section{Key Points for Decision Makers}

There appear to be disparities between the earnings of health economics, outcomes research, and market access professionals living in the USA compared to other countries; within each location, there are mild gender disparities.

There also appears to be greater earnings inequality outside the USA than within the USA.

Within each location, there may be more unequal distribution of men's earnings compared to women's earnings. 


\section{Introduction}

The health economics, outcomes research, and market access (HE/OR/MA) workforce provides economic reasoning for effective societal diffusion of discovery and innovation. Working closely with other healthcare professionals, as well as with social and behavioral scientists, it has played a crucial role in the translation of science and knowledge into sound health policies and outcomes. The current coronavirus disease 2019 (COVID-19) global pandemic has underscored the cross-functional nature and fundamental work of health economics and outcomes research (HE/OR) in addressing the negative effects of the pandemic in a timely manner [1-3].

Despite being one of the fastest growing and most innovative segments of the health-sector workforce across continents [4-9], HE/OR/MA professionals seldom are viewed as a cohesive group of workers bound by homogeneous work settings, complementary tasks, and congruous goals. Perhaps the apparent fragmentation has its roots in the fact that $\mathrm{HE} / \mathrm{OR} / \mathrm{MA}$ professionals are commonly found in a wide variety of institutions-private sector, government, and academia - with different expectations [10], which hinders the development of a stronger identity.

The specific focus of this paper is wage-and-salary earnings. Several studies indicate that pay is one of the most significant determinants of employees' motivation, attitudes, and behavior, especially pertaining to career choice, performance, and retention of worthwhile workers [11-13]; this is particularly relevant in light of the diffusion of these workers across health-sector institutions. Yet only four studies published within the last 30 years have addressed formally the earnings of HE/OR/MA professionals: Feldman and Morrisey [14] conducted a survey of health economists in 1989; Cawley and Morrisey [15] followed up with another survey of health economists in 2005; Carvajal et al. [16] broadened the analytical scope to include outcomes research and market access professionals in a survey conducted in 2015; and Ghosh et al. [17] identified variables associated with higher salaries.

This study sought to accomplish four purposes regarding HE/OR/MA professionals: (1) estimate their wage-and-salary earnings; (2) compare simultaneously male versus female and US versus non-US earnings levels; (3) assess the magnitude and importance of the effect of several human-capital and jobrelated covariates as determinants of earnings by gender and location; and (4) examine inequality in earnings distribution, also within gender and location.

\section{Methods}

This study was based on deidentified data voluntarily selfreported during the period January-March 2017 by HE/ OR/MA professionals who subscribed to HealthEconomics.com, which is a comprehensive network that serves as a worldwide link to the health economics, outcomes research, and pharma market access stakeholder communities; its purpose is to connect people with resources, ongoing research, and employment and educational opportunities. Every subscriber, about 25,000 of them, was invited to participate in the survey. Respondents were asked to disclose the annual wage-and-salary earnings received from their professional work, country where they worked, gender, age, highest academic degree attained, amount of work experience as an HE/OR/MA professional, whether they worked full time or part time, type of work performed, primary job level, and employer's main area of operations.

Annual wage-and-salary earnings, not including bonuses or commissions, were reported in US dollars; adjustments in purchasing power by location were not made. Age was reported in years. The categories for highest academic degree attained were baccalaureate (BA and BS), master's (MA, MS, MBA, and MPH), doctoral (PhD, $\mathrm{MD}$, and PharmD), and other. The categories for type of work performed were HE/OR (including patient-reported outcomes and health-related quality of life), market value or market access (including medical affairs, pricing, reimbursement, marketing, and advertising), technical operations (including medical writing, communications, biostatistics, epidemiology, information technology, and database analysis), academia, and other.

The categories for primary job level were top executive (chief executive officers, presidents, and vice-presidents), director (including chief and senior officers), associate or assistant director, manager, analyst (including specialists and research assistants), faculty member, and other. The categories for employer's main area of operations were pharmaceutical or biotechnology firm, contract research or consulting organization, academia, medical device firm, managed care (including insurance and pharmacy benefit) organization, and other (including healthcare providers and government, health technology assessment, and marketing/communications/advertising agencies).

\subsection{Earnings Levels and Related Variables}

A two-way classification model with multiple replications was designed to identify differences in earnings of the HE/ OR/MA professionals in the 2017 survey. One classification consisted of both genders $(i=1,2)$; the other classification distinguished between professionals living in and outside the USA $(j=1,2)$. The "living outside the USA" classification grouped observations from nations all over the world whose only commonality was that the respondents did not work on US soil. Although wide variations in some key variables were expected within this group, the paucity of 
observations in each country did not allow any other type of aggregation. Previous studies have shown that the gender earnings gap is greater in the liberal economies of Englishspeaking countries, particularly the USA, than in the corporatist economies of Continental Europe [16].

Within each gender-location cell, $n_{i j}$ replications were observed. The model posed the advantage of allowing both gender and location differences to be tested simultaneously and independently of each other, plus testing for a possible gender-location interaction effect. This design has been applied successfully in the analysis of variations in earnings and other variables in the pharmacist workforce [18] as well as earnings of HE/OR/MA professionals [16].

The linear additive model was as follows:

$Y_{i j k}=\mu+\gamma_{i}+\lambda_{j}+(\gamma \lambda)_{i j}+\varepsilon_{i j k}$

where $Y_{i j k}$ was the annual wage-and-salary earnings reported by the $k$ th professional of the $i$ th gender and the $j$ th location; $\mu$ was the overall mean; $\gamma_{i}$ was the systematic effect of the $i$ th gender; $\lambda_{j}$ was the systematic effect of the $j$ th location; $(\gamma \lambda)_{i j}$ was the gender-location interaction effect; $\varepsilon_{i j k}$ was the stochastic disturbance (random error) term of the $k$ th professional of the $i$ th gender and the $j$ th location; and $i=1$ for men and $i=2$ for women; $j=1$ for professionals living in the USA and $j=2$ for professionals living outside the USA; and $n_{i j}$ was the number of professionals of the $i$ th gender and the $j$ th location reporting their annual earnings.

The cutoff level for identifying statistical significance was established at $p=0.10$.

\subsection{Earnings Determinants}

Within each gender-location cell, an earnings determination model was formulated and tested using ordinary least squares to estimate gender and location disparities in the effect, if any, of several human-capital and job-related covariates on the earnings of HE/OR/MA professionals. Separate functions with identical covariates were estimated for the four cells to compare the direction, magnitude, and statistical significance of the coefficients. An alternative pooled model, in which the gender and/or location effect would be identified by dichotomous variables, was dismissed because of its likely incorrect assumption that the earnings responses to covariates were equal for all respondents regardless of gender and/or location [19, 20]. Disparities in response, if they existed, were the kind of empirical evidence pursued by this article.

The annual wage-and-salary earnings of HE/OR/MA professionals in the sample were hypothesized to be a function of age, highest academic degree attained, type of work performed, primary job level, and employer's main area of operations, as follows: $\ln Y_{i j k}=\alpha_{i j}+\beta_{1 i j} X_{i j k}+\beta_{2 i j} X_{i j k}^{2}+\delta_{i j} D_{i j k}+\tau_{i j} T_{i j k}+\varphi_{i j} J_{i j k}+\omega_{i j} E_{i j k}+u_{i j k}$

where $\ln Y_{i j k}$ was the natural logarithm value of annual wageand-salary earnings reported by the $k$ th professional of the $i$ th gender and the $j$ th location. $X_{i j k}$ was the age reported by the $k$ th professional of the $i$ th gender and the $j$ th location. $D_{i j k}$ was a dichotomous variable measuring the highest academic degree reportedly attained by the $k$ th professional of the $i$ th gender and the $j$ th location (it was assigned a value of 1 if the $k$ th professional reported having earned a doctoral degree, and a value of 0 otherwise). $T_{i j k}$ was a dichotomous variable measuring the type of work performed by the $k$ th professional of the $i$ th gender and the $j$ th location (it was assigned a value of 1 if the $k$ th professional reported working as a health economics or outcomes research specialist, and a value of 0 otherwise). $J_{i j k}$ was a dichotomous variable measuring the primary job level reported by the $k$ th professional of the $i$ th gender and the $j$ th location (it was assigned a value of 1 if the $k$ th professional reported being a top executive or director, and a value of 0 otherwise). $E_{i j k}$ was a dichotomous variable measuring the employer's main area of operations reported by the $k$ th professional of the $i$ th gender and the $j$ th location (it was assigned a value of 1 if the $k$ th professional reported working in a pharmaceutical or biotechnology firm, and a value of 0 otherwise). $\alpha_{i j}$ was the least-squares constant term estimated for the $i$ th gender and the $j$ th location equation. $\beta_{1 i j}$ and $\beta_{2 i j}$ were the least-squares coefficients of the linear and quadratic terms, respectively, estimated for age in the $i$ th gender and the $j$ th location equation. $\delta_{i j}, \tau_{i j}, \varphi_{i j}$, and $\omega_{i j}$ were the least-squares coefficients estimated for the dichotomous variables in the $i$ th gender and the $j$ th location equation. $u_{i j k}$ was the stochastic disturbance (random error) term of the $k$ th professional of the $i$ th gender and the $j$ th location, which was expected to be drawn from a normal, independent distribution with mean zero and variance $\sigma_{i j}^{2}$. $i=1$ for men and $i=2$ for women. $j=1$ for professionals living in the USA and $j=2$ for professionals living outside the USA. $n_{i j}$ was the number of professionals in the $i$ th gender and the $j$ th location equation.

HE/OR/MA professionals' earnings levels were logged to reduce the impact of outliers and allow interpretation of relative rather than absolute differences [21, 22]. The estimated least-squares coefficients in this semilog earnings determination model denoted exponential values. An addition of 0.693147 to the natural logarithm value of a number doubles the value of the number; conversely, a subtraction of 0.693147 from the natural logarithm value of a number cuts the value of the number by one-half.

The model included two human-capital covariates and three job-related covariates. For nominal variables in the dataset, only one category was identified in the equation to avoid multicollinearity and conserve degrees of freedom. The human-capital covariates were age as a proxy for work 
experience and educational attainment. Age, measured in years, had linear and quadratic components to measure direction and rate of change. Anticipating that more experience would lead to greater productivity and earnings up to a point beyond which obsolescence would begin to set in, the linear term was hypothesized to be positive and the quadratic term was hypothesized to be negative. Educational attainment, measured as a dichotomous variable for professionals with doctoral degrees, was hypothesized to have a positive coefficient denoting higher earnings levels than those of their peers without a doctoral degree.

The other covariates identified here focused on job-related characteristics. They included working as a health economist or outcomes research specialist, being a top executive or director, and working in a pharmaceutical or biotechnology firm. All three were dichotomous covariates whose effect on earnings was expected to be positive. HE/OR specialists were anticipated to earn relatively higher wages and salaries than professionals in other types of work because of their leadership role and specialized training [15], top executives and directors were expected to rank at the top of the income scale in their institutions, and workers in biopharmaceutical firms were foreseen to be well paid due to the fast growth pace of the market [23].

\subsection{Earnings Inequality}

Inequality in the distribution of wage-and-salary earnings within each gender-location cell was estimated using three measures of dispersion: the lower median share, the 90-10 decile ratio, and the Gini coefficient. These were the three indicators used by Carvajal et al. [16] in the analysis of a similar data set gathered in 2015. The indicators focused on different aspects of inequality, each measuring a perspective of earnings disparity that might be bypassed by the others. It is not uncommon for analysts to estimate several indicators in search of a more comprehensive view of a particular earnings distribution [24-26].

The lower median share measured the percentage of total earnings reported by the lower half of HE/OR/MA professionals in the sample, arranged in descending order. Its advantages are ease of calculation and portrayal of earnings split down the middle of the distribution; its main disadvantage is the inability to provide an insight into the nature of the spread within either half of earners [27]. Lower values of this indicator are indicative of greater inequality.

The 90-10 decile ratio measured the aggregate earnings reported by participants in the top $10 \%$ of the distribution divided by the aggregate earnings of the bottom $10 \%$. It focuses solely on earnings reported at both ends of the array without considering the $80 \%$ of earners in the middle. Greater inequality is portrayed by higher values of this indicator [28].
The Gini coefficient is the most frequently used measure of inequality [29-31], but it is difficult to compute. Here, it was obtained by averaging the differences between all possible pairs of earnings levels in the data set [32]. The Gini coefficient is more sensitive to changes in the middle of the distribution than to changes at either end; one of its disadvantages is that it is not able to identify different kinds of inequality [33]. Higher values of this indicator denote greater inequality.

\section{Results}

A total of $372 \mathrm{HE} / \mathrm{OR} / \mathrm{MA}$ professionals participated in the study by providing answers to all relevant questions. This represented approximately $1.5 \%$ of HealthEconomics. com subscribers. The number of respondents was slightly smaller than the one reported for the previous HE/OR/MA professionals' income study, but it compared favorably with those reported by similar undertakings [34-36] and it allowed enough degrees of freedom for meaningful statistical inferences. Of the 372 participants, 195 were men (52.4\%) and 177 were women (47.6\%), and 232 lived in the USA (62.4\%), while 140 lived outside the USA (37.6\%). The male-female breakdown was similar for both locations. The distribution was similar to the distribution of the approximately 25,000 subscribers to HealthEconomics.com (49.2\% men and $50.8 \%$ women, $56.0 \%$ living in the USA and $44.0 \%$ living outside the USA). The country composition of the 140 respondents living outside the USA was as follows: 23 were from the UK (16.4\%), 16 were from Switzerland (11.4\%), 48 were from the rest of Europe (34.3\%), 19 were from India (13.6\%), 11 were from Canada (7.9\%), and the additional 23 respondents were from other parts of the world (16.4\%).

\subsection{Earnings Levels and Related Variables}

The estimated mean and standard deviation values of wages and salaries by gender and location reportedly earned by the HE/OR/MA professionals in the sample are presented in Table 1. Within each location, men earned higher wages and salaries than women, and within each gender, respondents living in the USA earned higher wages and salaries than those living outside the USA. Both gender and location differences were statistically significant, but no significant interaction effect was detected. The US wage-and-salary figures were higher than the ones reported in the 2015 survey, particularly for women, but for both male and female participants living outside the USA, reported wages and salaries in 2017 declined considerably vis-a-vis those reported 2 years prior. The earnings drop of non-US professionals was greater than the earnings gain of their US counterparts, 
Table 1 Number of observations in the sample and estimated values of the mean and standard deviation of $\mathrm{HE} /$ OR/MA professionals' annual wage-and-salary earnings (in US dollars) by gender and location, 2017

\begin{tabular}{lllll}
\hline Location & Indicator & Gender & \\
\cline { 3 - 5 } & & $\begin{array}{l}\text { Men } \\
(i=1)\end{array}$ & $\begin{array}{l}\text { Women } \\
(i=2)\end{array}$ & Both genders \\
\hline US & Number of observations & 120 & 112 & 232 \\
$(j=1)$ & Mean (\$) & 181,917 & 163,415 & 172,985 \\
& Standard deviation (\$) & 108,725 & 66,521 & 91,114 \\
Non-US & Number of observations & 75 & 65 & 140 \\
$(j=2)$ & Mean (\$) & 103,900 & 91,885 & 98,321 \\
& Standard deviation $(\$)$ & 73,037 & 55,534 & 65,544 \\
Both locations & Number of observations & 195 & 177 & 372 \\
& Mean (\$) & 151,910 & 137,147 & 144,886 \\
& Standard deviation $(\$)$ & 103,604 & 71,470 & 89,947 \\
\hline
\end{tabular}

Mean income differences between genders: $F=2.99(p=0.084)$

Mean income differences between locations: $F=71.88$ ( $p \leq 0.001)$

Gender-location interaction effect: $F=0.14$ (not statistically significant) so the overall 2017 reported wages and salaries were $1.7 \%$ less than in 2015.

The empirical evidence from the sample revealed that compared to US men's average wages and salaries, US women earned $89.8 \%$ (earnings gap of $10.2 \%$ ), non-US men earned $57.1 \%$ (earnings gap of $42.9 \%$ ), and non-US women earned $50.5 \%$ (earnings gap of $49.5 \%$ ). These estimates did not take into account purchasing power parity and were unadjusted for possible determinants. They might have been influenced by differences in the number of hours worked, human-capital characteristics, job-related characteristics, and/or employer's preferences, as well as by inter-country variations in macroeconomic variables such as economic growth, unemployment, and tax structure, to name a few.

Respondents' estimated values of selected variables commonly hypothesized to explain disparities in wages and salaries are presented in Table 2 . The results indicated that men and women in each location reported approximately the same age, but HE/OR/MA professionals living in the USA were older than those not living in the USA. Within each location, men and women exhibited approximately the same percentage of doctoral degrees, but participants living in the USA reported attaining a higher percentage of doctoral degrees than participants living outside the USA.

In terms of job-related characteristics, proportionately more women than men in each location, and more US than non-US respondents, reported working part time, although for all practical purposes, virtually all respondents of both genders and both locations worked full time. The percentages of professionals who reported their job function as HE/ OR specialists were similar for both genders, but greater for US residents than for respondents living outside the USA. The percentage composition of primary-job level showed more male than female respondents holding a top executive or director position in their place of employment; within gender, the proportion of participants who were top executives or directors was greater for US than for nonUS residents. Finally, in terms of employer's main area of operations, the relative gender-location concentration was the opposite of the one portrayed by earnings: within each location, the percentage of HE/OR/MA professionals in the sample working in pharmaceutical or biotechnology firms was lower for men than for women, and within each gender, it was lower in the USA than outside the USA.

\subsection{Earnings Determinants}

The estimated least-squares coefficients, standard errors, and levels of significance of the covariates of the earnings determination model are presented in Table 3. The coefficient values of all covariates were statistically significant for at least one gender-location group, and most coefficient values were significant for both genders and both location groups. All four $F$ ratios were significant, and the adjusted $R^{2}$ values suggested that between one-half and two-thirds of the variation in the natural logarithm values of earnings was explained by the covariates in the model.

The age least-squares coefficients behaved as expectedpositive linear terms and negative quadratic terms, all statistically significant. According to these estimates for HE/OR/ MA professionals in the sample, on average, an additional year of age yielded an $11.8 \%$ increase in the earnings of US men, a $6.0 \%$ increase in the earnings of US women, a 9.3\% increase in the earnings of non-US men, and a $14.9 \%$ increase in the earnings of non-US women. Attainment of a doctoral degree, the other human-capital covariate, was significant only for US women, whose earnings were, on average, $25.0 \%$ higher than those of women without doctoral degrees living in the USA.

Working as an HE/OR specialist was significant for practitioners living outside the USA, but not for US practitioners; compared to their counterparts of the same gender living 
outside the USA who did not work as HE/OR specialists, male HE/OR specialists in the sample earned $33.6 \%$ less, but female HE/OR specialists earned $27.9 \%$ higher wages and salaries. Being a top executive or director was significant in all four gender-location categories. Compared to respondents of the same gender and location who were not top executives or directors, US men reported $63.4 \%$ higher earnings, US women reported $53.1 \%$ higher earnings, non-US men reported $82.9 \%$ higher earnings, and non-US women reported $85.3 \%$ higher earnings. Working in a pharmaceutical or biotechnology firm also was statistically significant across the board; compared to their peers of the same gender and location who worked in other areas of operations, these HE/OR/MA professionals earned $30.0 \%$ more if they were men living in the USA, $27.1 \%$ more if they were women living in the USA, $46.0 \%$ more if they were men living outside the USA, and $49.9 \%$ more if they were women living outside the USA.

\subsection{Earnings Inequality}

The estimated values of participants' lower median shares, 90-10 decile ratios, and Gini coefficients are presented in Table 4. Lower median share values were similar for men and women within each location, but they were lower for HE/ OR/MA professionals living outside the USA, thus suggesting greater inequality in the distribution of wages and salaries than for HE/OR/MA professionals living in the USA. In other

Table 2 Estimated sample values of variables hypothesized to influence HE/OR/MA professionals' annual wage-and-salary earnings by gender and location, 2017

\begin{tabular}{|c|c|c|c|c|c|}
\hline \multirow[t]{2}{*}{ Variable } & \multirow[t]{2}{*}{ Location } & \multirow[t]{2}{*}{ Variable categories } & \multicolumn{3}{|l|}{ Gender } \\
\hline & & & $\begin{array}{l}\text { Men } \\
(i=1)\end{array}$ & $\begin{array}{l}\text { Women } \\
(i=2)\end{array}$ & Both genders \\
\hline \multirow[t]{3}{*}{ Age (years), mean (standard deviation) } & $\mathrm{US}(j=1)$ & & $42.9(10.6)$ & $41.9(10.3)$ & $42.4(10.4)$ \\
\hline & Non-US $(j=2)$ & & $39.7(10.6)$ & $39.2(9.2)$ & $39.4(9.9)$ \\
\hline & Both locations & & $41.6(10.7)$ & $40.9(9.9)$ & $41.3(10.3)$ \\
\hline \multirow[t]{3}{*}{ Highest academic degree attained (\%) } & $\mathrm{US}(j=1)$ & $\begin{array}{l}\text { Baccalaureate } \\
\text { Master's } \\
\text { Doctoral } \\
\text { Other }\end{array}$ & $\begin{array}{l}11.0 \\
39.0 \\
50.0 \\
-\end{array}$ & $\begin{array}{l}8.1 \\
40.5 \\
50.5 \\
0.9\end{array}$ & $\begin{array}{l}9.6 \\
39.8 \\
50.2 \\
0.4\end{array}$ \\
\hline & Non-US $(j=2)$ & $\begin{array}{l}\text { Baccalaureate } \\
\text { Master's } \\
\text { Doctoral } \\
\text { Other }\end{array}$ & $\begin{array}{l}6.9 \\
51.4 \\
38.9 \\
2.8\end{array}$ & $\begin{array}{l}14.3 \\
50.8 \\
33.3 \\
1.6\end{array}$ & $\begin{array}{l}10.4 \\
51.0 \\
36.4 \\
2.2\end{array}$ \\
\hline & Both locations & $\begin{array}{l}\text { Baccalaureate } \\
\text { Master's } \\
\text { Doctoral } \\
\text { Other }\end{array}$ & $\begin{array}{l}9.5 \\
43.7 \\
45.7 \\
1.1\end{array}$ & $\begin{array}{l}10.3 \\
44.2 \\
44.3 \\
1.2\end{array}$ & $\begin{array}{l}9.9 \\
44.0 \\
45.0 \\
1.1\end{array}$ \\
\hline \multirow[t]{3}{*}{ Employment status (\%) } & $\mathrm{US}(j=1)$ & $\begin{array}{l}\text { Full time } \\
\text { Part time }\end{array}$ & $\begin{array}{l}98.3 \\
1.7\end{array}$ & $\begin{array}{l}93.7 \\
6.3\end{array}$ & $\begin{array}{l}96.1 \\
3.9\end{array}$ \\
\hline & Non-US $(j=2)$ & $\begin{array}{l}\text { Full time } \\
\text { Part time }\end{array}$ & $\begin{array}{l}100.0 \\
-\end{array}$ & $\begin{array}{l}98.5 \\
1.5\end{array}$ & $\begin{array}{l}99.3 \\
0.7\end{array}$ \\
\hline & Both locations & $\begin{array}{l}\text { Full time } \\
\text { Part time }\end{array}$ & $\begin{array}{l}99.0 \\
1.0\end{array}$ & $\begin{array}{l}95.4 \\
4.6\end{array}$ & $\begin{array}{l}97.3 \\
2.7\end{array}$ \\
\hline \multirow[t]{3}{*}{ Type of work $(\%)$} & $\mathrm{US}(j=1)$ & $\begin{array}{l}\text { Health economics and outcomes research } \\
\text { Market value or market access } \\
\text { Technical operations } \\
\text { Academia } \\
\text { Other }\end{array}$ & $\begin{array}{l}46.7 \\
36.6 \\
10.0 \\
4.2 \\
2.5\end{array}$ & $\begin{array}{l}43.7 \\
30.4 \\
17.8 \\
4.5 \\
3.6\end{array}$ & $\begin{array}{l}45.3 \\
33.6 \\
13.8 \\
4.3 \\
3.0\end{array}$ \\
\hline & Non-US $(j=2)$ & $\begin{array}{l}\text { Health economics and outcomes research } \\
\text { Market value or market access } \\
\text { Technical operations } \\
\text { Academia } \\
\text { Other }\end{array}$ & $\begin{array}{l}36.0 \\
52.0 \\
6.7 \\
1.3 \\
4.0\end{array}$ & $\begin{array}{l}40.0 \\
44.6 \\
7.7 \\
3.1 \\
4.6\end{array}$ & $\begin{array}{l}37.9 \\
48.6 \\
7.1 \\
2.1 \\
4.3\end{array}$ \\
\hline & Both locations & $\begin{array}{l}\text { Health economics and outcomes research } \\
\text { Market value or market access } \\
\text { Technical operations } \\
\text { Academia } \\
\text { Other }\end{array}$ & $\begin{array}{l}42.6 \\
42.6 \\
8.6 \\
3.1 \\
3.1\end{array}$ & $\begin{array}{l}42.3 \\
35.6 \\
14.1 \\
4.0 \\
4.0\end{array}$ & $\begin{array}{l}42.5 \\
39.2 \\
11.3 \\
3.5 \\
3.5\end{array}$ \\
\hline
\end{tabular}


Table 2 (continued)

\begin{tabular}{|c|c|c|c|c|c|}
\hline \multirow[t]{2}{*}{ Variable } & \multirow[t]{2}{*}{ Location } & \multirow[t]{2}{*}{ Variable categories } & \multicolumn{3}{|c|}{ Gender } \\
\hline & & & $\begin{array}{l}\text { Men } \\
(i=1)\end{array}$ & $\begin{array}{l}\text { Women } \\
(i=2)\end{array}$ & Both genders \\
\hline \multirow[t]{3}{*}{ Primary job level (\%) } & $\mathrm{US}(j=1)$ & $\begin{array}{l}\text { Top executive } \\
\text { Director } \\
\text { Associate or assistant director } \\
\text { Manager } \\
\text { Analyst } \\
\text { Faculty member } \\
\text { Other }\end{array}$ & $\begin{array}{l}25.0 \\
33.3 \\
8.3 \\
11.7 \\
8.3 \\
5.0 \\
8.4\end{array}$ & $\begin{array}{l}16.0 \\
29.5 \\
15.2 \\
15.2 \\
8.0 \\
2.7 \\
13.4\end{array}$ & $\begin{array}{l}20.7 \\
31.5 \\
11.6 \\
13.4 \\
8.2 \\
3.9 \\
10.7\end{array}$ \\
\hline & Non-US $(j=2)$ & $\begin{array}{l}\text { Top executive } \\
\text { Director } \\
\text { Associate or assistant director } \\
\text { Manager } \\
\text { Analyst } \\
\text { Faculty member } \\
\text { Other }\end{array}$ & $\begin{array}{l}14.7 \\
33.3 \\
4.0 \\
28.0 \\
16.0 \\
1.3 \\
2.7\end{array}$ & $\begin{array}{l}4.6 \\
24.6 \\
9.3 \\
33.8 \\
20.0 \\
1.5 \\
6.2\end{array}$ & $\begin{array}{l}10.0 \\
29.3 \\
6.4 \\
30.7 \\
17.9 \\
1.4 \\
4.3\end{array}$ \\
\hline & Both locations & $\begin{array}{l}\text { Top executive } \\
\text { Director } \\
\text { Associate or assistant director } \\
\text { Manager } \\
\text { Analyst } \\
\text { Faculty member } \\
\text { Other }\end{array}$ & $\begin{array}{l}21.0 \\
33.3 \\
6.7 \\
17.9 \\
11.3 \\
3.6 \\
6.2\end{array}$ & $\begin{array}{l}11.9 \\
27.7 \\
13.0 \\
22.0 \\
12.4 \\
2.3 \\
10.7\end{array}$ & $\begin{array}{l}16.6 \\
30.6 \\
9.7 \\
19.9 \\
11.8 \\
3.0 \\
8.4\end{array}$ \\
\hline \multirow[t]{3}{*}{ Employer's main area of operations (\%) } & $\mathrm{US}(j=1)$ & $\begin{array}{l}\text { Pharmaceutical or biotechnology } \\
\text { Contract research or consulting } \\
\text { Academia } \\
\text { Medical device } \\
\text { Managed care } \\
\text { Other }\end{array}$ & $\begin{array}{l}40.0 \\
27.5 \\
5.8 \\
10.8 \\
10.0 \\
5.9\end{array}$ & $\begin{array}{l}44.6 \\
24.1 \\
5.4 \\
8.0 \\
7.1 \\
10.8\end{array}$ & $\begin{array}{l}42.2 \\
25.9 \\
5.6 \\
9.5 \\
8.6 \\
8.2\end{array}$ \\
\hline & Non-US $(j=2)$ & $\begin{array}{l}\text { Pharmaceutical or biotechnology } \\
\text { Contract research or consulting } \\
\text { Academia } \\
\text { Medical device } \\
\text { Managed care } \\
\text { Other }\end{array}$ & $\begin{array}{l}52.0 \\
26.6 \\
1.3 \\
5.3 \\
1.3 \\
13.5\end{array}$ & $\begin{array}{l}56.9 \\
24.7 \\
3.1 \\
7.7 \\
- \\
7.6\end{array}$ & $\begin{array}{l}54.3 \\
25.7 \\
2.1 \\
6.4 \\
0.7 \\
10.8\end{array}$ \\
\hline & Both locations & $\begin{array}{l}\text { Pharmaceutical or biotechnology } \\
\text { Contract research or consulting } \\
\text { Academia } \\
\text { Medical device } \\
\text { Managed care } \\
\text { Other }\end{array}$ & $\begin{array}{l}44.6 \\
27.2 \\
4.1 \\
8.7 \\
6.7 \\
8.7\end{array}$ & $\begin{array}{l}49.2 \\
24.3 \\
4.5 \\
7.9 \\
4.5 \\
9.6\end{array}$ & $\begin{array}{l}46.8 \\
25.8 \\
4.3 \\
8.3 \\
5.7 \\
9.1\end{array}$ \\
\hline
\end{tabular}

HE/OR/MA health economics, outcomes research, and market access

words, the fraction of total earnings reported by the lower half of respondents (arranged in descending order) was higher for the USA than for all other countries taken globally.

A pattern of more inequality in the distribution of wages and salaries of HE/OR/MA professionals living outside than in the USA was also suggested by the relatively higher values of the estimated 90-10 decile ratios. In addition, the empirical evidence pointed toward greater disparity between the top and bottom deciles within the distribution of men's earnings than within the distribution of women's earnings in each location.

The estimated Gini coefficient values were higher for respondents living outside the USA than for US respondents, which reinforced the empirical pattern of inequality portrayed by the two other indicators: the distribution of HE/OR/MA professionals' earnings reported in the sample was more unequal outside the USA than in the USA. Although the male Gini coefficient values exceeded the female values in each location, the difference was rather mild and might be largely attributable to random variation. 
Table 3 Estimated least-squares coefficients, their standard errors (in parentheses), and (two-tail) levels of significance of covariates in the model by gender and location, 2017

\begin{tabular}{|c|c|c|c|c|c|}
\hline \multirow[t]{3}{*}{ Variable } & \multirow[t]{3}{*}{ Term } & \multicolumn{4}{|c|}{ Estimated least-squares coefficients, standard errors, and levels of significance } \\
\hline & & \multicolumn{2}{|c|}{ Living in the USA $(j=1)$} & \multicolumn{2}{|c|}{ Living outside the USA $(j=2)$} \\
\hline & & $\operatorname{Men}(i=1)$ & Women $(i=2)$ & $\operatorname{Men}(i=1)$ & Women $(i=2)$ \\
\hline Constant & $\alpha$ & 8.9861 & 9.9857 & 8.8019 & 7.4529 \\
\hline Age (linear) & $\beta_{1}$ & $0.1134 *(0.0241)$ & $0.0590^{\ddagger}(0.0259)$ & $0.0907^{\ddagger}(0.0393)$ & $0.1422 *(0.0476)$ \\
\hline Age (quadratic) & $\beta_{2}$ & $-0.0012 *(0.0003)$ & $-0.0005^{\dagger}(0.0003)$ & $-0.0009^{\dagger}(0.0005)$ & $-0.0014^{\ddagger}(0.0006)$ \\
\hline Doctoral degree & $\delta$ & $0.0324(0.0786)$ & $0.2228 *(0.0673)$ & $0.0540(0.1145)$ & $0.0418(0.1273)$ \\
\hline HE/OR specialist & $\tau$ & $-0.0395(0.0784)$ & $-0.0296(0.0668)$ & $-0.4090 *(0.1300)$ & $0.2458^{\dagger}(0.1372)$ \\
\hline Top executive or director & $\varphi$ & $0.4907 *(0.0830)$ & $0.4260 *(0.0699)$ & $0.6036 *(0.1322)$ & $0.6169 *(0.1382)$ \\
\hline $\begin{array}{l}\text { Pharmaceutical or bio- } \\
\text { technology firm }\end{array}$ & $\omega$ & $0.2624 *(0.0745)$ & $0.2401 *(0.0656)$ & $0.3787 *(0.1139)$ & $0.4049 *(0.1306)$ \\
\hline$F$ statistic & & $19.03 *$ & $22.44 *$ & $24.63^{*}$ & $15.57 *$ \\
\hline Adjusted $R^{2}$ & & 0.485 & 0.541 & 0.666 & 0.585 \\
\hline
\end{tabular}

$H E$ health economics, $O R$ outcomes research

*Statistically significant $(p \leq 0.01)$

${ }^{\ddagger}$ Statistically significant $(p \leq 0.05)$

${ }^{\dagger}$ Statistically significant $(p \leq 0.10)$

Table 4 Estimated sample values of three measures of dispersion of HE/OR/MA professionals' annual wage-and-salary earnings by gender and location, 2017

\begin{tabular}{llccc}
\hline $\begin{array}{l}\text { Measure of disper- } \\
\text { sion }\end{array}$ & Location & \multicolumn{3}{l}{ Gender } \\
\cline { 3 - 5 } & & Men & Women & Both genders \\
\hline Lower median share & US & 0.314 & 0.337 & 0.324 \\
& Non-US & 0.212 & 0.250 & 0.235 \\
& Both locations & 0.267 & 0.288 & 0.278 \\
90-10 decile ratio & US & 7.45 & 4.93 & 6.31 \\
& Non-US & 10.20 & 8.07 & 9.31 \\
Gini coefficient & Both locations & 13.96 & 11.02 & 12.53 \\
& US & 0.273 & 0.228 & 0.254 \\
& Non-US & 0.385 & 0.334 & 0.365 \\
& Both locations & 0.334 & 0.293 & 0.317 \\
\hline
\end{tabular}

HE/OR/MA health economics, outcomes research, and market access

\section{Discussion}

The empirical evidence of this study points toward possibly substantial disparities between the observed wage-and-salary earnings of HE/OR/MA professionals living in the USA and those living in other countries. Unfortunately, data on the number of hours worked per participant were not available. The number of hours worked per week, month, etc. might have contributed to the portrayal of a more comprehensive view of earnings disparities. However, the results indicate that only a few of the HE/OR/MA professionals in the sample worked part time; therefore, earnings comparisons between genders and between locations seem to be appropriate.
When both genders were taken together, non-US participants reported an earnings gap of $43.2 \%$ with respect to their counterparts residing and working in the USA. Curiously, the location earnings gap was virtually the same for both men and women. Gender disparities in wages and salaries, regardless of location, were less notable, although they were statistically significant. This did not accord with the findings of Ghosh et al. [17]; perhaps the statistical significance between genders found here may be explained by the disaggregation of observations between those living in and outside the USA. When the earnings of respondents from all locations were grouped solely by gender, the female gap was $9.7 \%$, lower than the gap reported by Carvajal et al. [16]. The female earnings gap also was very similar for US and non-US HE/OR/MA professionals in the sample.

Along with the increase in US earnings and decline in non-US earnings observed from 2015 to 2017 (US earnings increased by $5 \%$, while non-US earnings decreased by $14 \%$ ), the participants' gender and location distribution of age in both surveys remained approximately the same; the percentage of both genders who attained a doctoral degree decreased in the USA, but increased outside the USA and, within each gender, the small fraction of part-time work increased in the USA, but decreased outside the USA. Compared to the results of the 2015 sample, the proportion of HE/OR/MA professionals in the 2017 sample who reported their job function as HE/OR specialists declined in all categories except women living outside the USA; the percentage who reported holding a top executive or director position remained the same in the USA, but outside the USA it went up for men and down for women; and the proportion of 
respondents working in a pharmaceutical or biotechnology firm went down for all categories except US men.

Since location disparities, and to a lesser extent gender disparities, in participants' wage-and-salary earnings might have been influenced by inter-country variations in macroeconomic variables, a review of the estimated values of the effect of human-capital and job-related covariates as earnings determinants in the model seemed relevant. Unfortunately, the empirical evidence of the human-capital covariates was mixed and inconclusive. Older age, a proxy for greater professional experience, appeared to increase in the USA the earnings of men more than the earnings of women, while outside the US, women benefitted more from experience than did men; furthermore, in terms of earnings, US men benefitted more from experience than non-US men, while non-US women seemed to benefit more from experience than US women. The other human-capital covariate, attainment of a doctoral degree, lacked statistical significance for three of the four gender-location groupings, so no comparisons could be made. The higher wages and salaries earned by US women with doctoral degrees, relative to US women without doctoral degrees, accorded with the findings by Cawley and Morrisey [15]. The findings here seemed to suggest that attaining a doctoral degree might be a wage-and-salary equalizer for female HE/OR/MA professionals in the USA.

The behavior of the job-related covariates was more consistent. The estimated male and female coefficients of non-US respondents who identified themselves as HE/OR specialists possessed statistical significance, whereas the coefficients of US HE/OR specialists did not. The effect, however, was different for men and women. Contrary to expectations, male HE/OR specialists in the sample living outside the USA earned lower wages and salaries than their counterparts working in other job functions, while for women the opposite was the case-female HE/OR specialists living outside the USA reported higher earnings than those in other types of work.

Both men and women living outside the USA who reported their primary job level as top executive or director benefitted relatively more from their position vis-a-vis those of the same gender who were neither top executives nor directors than did their US counterparts. (The positive sign of the estimated coefficients conformed to expectations.) Part of this differential may be related to the greater gender percentage of HE/OR/MA professionals in the sample observed working at these job levels in the USA than outside the USA. Along the same lines, however, within each location, the fraction of male top executives and directors exceeded substantially the fraction of women; yet the values of the least-squares coefficients for both genders were analogous.

A similar trend was observed with the covariate measuring employer's main area of operations. Both non-US men and women who reported working in a pharmaceutical or biotechnology firm earned relatively higher wages and salaries compared to those working for other types of employers than did their counterparts of the same gender living in the USA. But in this case, the percentage of non-US participants working in pharmaceutical or biotechnology firms was greater than the percentage of US participants. In all equations, the overall $F$ ratio values were statistically significant and the adjusted $R^{2}$ values indicated that the covariates specified in the model provided a good fit for both men and women as well as for US and non-US residents.

In terms of disparities in the distribution of reported earnings, all three indicators pointed toward greater inequality outside the USA than within the USA, which was consistent with the findings of Carvajal et al. [16]. Inter-country variations in price levels, exchange rates, tax systems, and other macroeconomic variables probably influenced the greater disparity. Within each location, the distribution of men's wages and salaries was found to be consistently more unequal than the distribution of women's wages and salaries, even though relatively more women than men reported working part time. This finding accorded with those of Carvajal et al. [32] and Dale-Olsen and Østbakken [37], and probably reflected greater competitiveness within men than within women. When compared with the results of the 2015 survey, the evidence here also pointed towards an increase in earnings inequality over the 2 -year period. For most gender-location classifications, the lower median share values went down, the 90-10 decile ratio values went up, and the Gini coefficient values went down.

\subsection{Limitations}

Several limitations may be identified throughout this paper that make the findings exploratory in nature. The most severe limitation was gathering the information from a convenience sample. The number of observations was relatively small. Although the sample exhibited similar gender and location compositions to the population from which it was drawn, respondents' socioeconomic characteristics and earnings patterns might have differed from those of HE/OR/MA professionals who were not subscribers to HealthEconomics. com or, while being subscribers, did not participate in the survey. Thus, the results reported here cannot be extrapolated to the global HE/OR/MA community.

The study relied on cross-sectional data, which were inadequate to address changes over time in the values and distribution of wages and salaries. The values of wage-andsalary earnings, reported in US dollars by participants, were not adjusted for purchasing power, tax structures, or other internal market conditions in each country; this limitation affected not only variation of earnings outside the USA, but it also affected variation within the USA, as different parts 
of the country experienced differences in prices and taxes. The net effect probably was an upward bias in the estimated indicators of inequality, affecting the distribution of earnings outside the USA to a greater extent than within the USA, as the effect of heterogeneous government networks, healthcare delivery systems, and institutional regulations was not taken into consideration.

Another limitation was reliance on self-reported wageand-salary data not validated for accuracy with employers. Other data such as age, level of education, type of work performed, primary job level, and employer's main area of operations were not validated either. Furthermore, since all participants in the sample were working, their responses were subject to a sample selection bias [36].

Still another limitation was the omission of some covariates measuring determinants of wages and salaries commonly identified in the literature. For example, data on the average number of hours worked per week or per month might have allowed the formulation of more precise earnings determination functions. Similarly, the addition of certain job-preference variables (i.e., commuting distance/ time, availability of flexible work schedules, etc.) or jobsatisfaction variables (i.e., job atmosphere, relations with peers and supervisors, etc.) might have allowed the measurement of compensating differentials and established the relative importance of wages and salaries vis-a-vis other work-related variables.

\section{Conclusion}

Despite its limitations, this study was successful in estimating the wage-and-salary earnings of a sample of $\mathrm{HE} /$ OR/MA professionals from multiple countries, comparing simultaneously male versus female and US versus non-US earnings levels, assessing the magnitude and importance of the effect of several human-capital and job-related covariates on wages and salaries by gender and location, and examining inequality in the distribution of earnings. It has provided a point of comparison with earlier studies and has shed light into the mechanics of one of the most innovative and fastest growing health-sector workforce segments in developed as well as emerging nations. Further work is needed to research the apparent trend toward greater earnings inequality, enlarge the segment of HE/OR/MA professionals under study, and broaden the scope of inquiry to include human-capital and job-related indicators beyond those explored here, as well as the institutional forces that contribute to the work of HE/OR/MA professionals in multiple and heterogeneous markets throughout the world. Such an endeavor is likely to present an opportunity to reduce the time needed to formulate research questions, increase the quality of the answers, and expand and refine HE/OR/MA professionals' involvement in the rational analysis of the provision of healthcare services.

\section{Compliance with ethical standards}

Conflict of interest Authors Ioana Popovici, Manuel J. Carvajal, and Silvia E. Rabionet declare that they have no conflict of interest. Author Patti Peeples is the founder of HealthEconomics.com, which publishes and owns the rights to the salary survey data.

Funding This research was supported solely by internal Nova Southeastern University funds. It did not receive any specific grant from funding agencies in the public, commercial, or not-for-profit sectors.

Ethical approval This research was exempt because respondents remained anonymous throughout the study.

Informed consent Informed consent was obtained from all individual participants included in the study when they answered the survey questions.

Consent for publication Not applicable.

Availability of data and material The datasets generated and/or analyzed in the current study are not publicly available. Author Patti Peeples is the founder of HealthEconomics.com, which publishes and owns the rights to the HEOR/Market Access Salary Survey data.

Code availability Data were analyzed using StataSE 15 software.

Authors' contributions All authors contributed equally to the study design and preparation of the manuscript. IP and MC analyzed and interpreted the data. All authors read and approved the final manuscript.

Open Access This article is licensed under a Creative Commons Attribution-NonCommercial 4.0 International License, which permits any non-commercial use, sharing, adaptation, distribution and reproduction in any medium or format, as long as you give appropriate credit to the original author(s) and the source, provide a link to the Creative Commons licence, and indicate if changes were made. The images or other third party material in this article are included in the article's Creative Commons licence, unless indicated otherwise in a credit line to the material. If material is not included in the article's Creative Commons licence and your intended use is not permitted by statutory regulation or exceeds the permitted use, you will need to obtain permission directly from the copyright holder. To view a copy of this licence, visit http://creativecommons.org/licenses/by-nc/4.0/.

\section{References}

1. Bavel JJ, Baicker K, Boggio PS, Capraro V, Cichocka A, Cikara $\mathrm{M}$, et al. Using social and behavioural science to support COVID19 pandemic response. Nat Hum Behav. 2020;4:460-71.

2. Younes GA, Ayoubi C, Ballester O, Cristelli G, de Rassenfosse G, Foray D, et al. COVID-19: insights from innovation economists. Sci Public Policy. 2020. https://doi.org/10.1093/scipol/scaa028.

3. Gans J. Economics in the age of COVID-19. Cambridge: MIT; 2020 . 
4. Cumming J. Health economics and health policy: experiences from New Zealand. Appl Health Econ Health Policy. 2015;13(3):281-9.

5. Dang A, Likhar N, Alok U. Importance of economic evaluation in health care: an Indian perspective. Value Health Reg Issues. 2016;9:78-83.

6. Garrison LP Jr, Pauly MV, Willke RJ, Neumann PJ. An overview of value, perspective, and decision context - a health economics approach: an ISPOR Special Task Force report [2]. Value Health. 2018;21(2):124-30.

7. Ghorashi N, Alavirad A, Eslami MR. The study on factors of health economics and economic growth in Iran. J Community Health Res. 2013;2(3):208.

8. Liu GG, Eggleston K, Hu T-w. Emerging health economics and outcomes research in the Asia-Pacific region. Value Health. 2008;II.

9. Mills A. Reflections on the development of health economics in low- and middle-income countries. Proc R Soc B Biol Sci. 2014;281(1789):20140451.

10. Morrisey MA, Cawley J. US health economists: who we are and what we do. Health Econ. 2008;17(4):535-43.

11. Gardner DG, Van Dyne L, Pierce JL. The effects of pay level on organization-based self-esteem and performance: a field study. J Occup Organ Psychol. 2004;77(3):307-22.

12. Milkovich GM, Newman JM. Compensation. Burr-Ridge, IL: Irwin McGraw-Hill; 2004.

13. Vandenberghe $\mathrm{C}$, Tremblay $\mathrm{M}$. The role of pay satisfaction and organizational commitment in turnover intentions: a two-sample study. J Bus Psychol. 2008;22(3):275-86.

14. Feldman R, Morrisey MA. Health economics: a report on the field. J Health Polit Policy Law. 1990;15(3):627-46.

15. Cawley J, Morrisey MA. The earnings of US health economists. J Health Econ. 2007;26(2):358-72.

16. Carvajal MJ, Peeples P, Popovici I. A probe into the wages and salaries of health economics, outcomes research, and market access professionals. Appl Health Econ Health Policy. 2019;17(5):741-51.

17. Ghosh S, Rascati KL, Shah A, Peeples P. Predictors of annual base salary for health economics, outcomes research, and market access professionals in the biopharmaceutical industry. J Manag Care Spec Pharm. 2019;25(12):1328-33.

18. Carvajal MJ, Popovici I. Interaction of gender and age in pharmacists' labour outcomes. J Pharm Health Serv Res. 2016;7(1):23-9.

19. Black DA, Haviland AM, Sanders SG, Taylor LJ. Gender wage disparities among the highly educated. J Hum Resour. 2008;43(3):630-59.

20. Yap M. Slicing and dicing the gender/racial earnings differentials. Int J Manpow. 2010;31(4):466-88.
21. Carvajal MJ, Armayor GM. The life-cycle argument: age as a mediator of pharmacists' earnings. Res Social Adm Pharm. 2015;11(1):129-33.

22. Carvajal MJ, Popovici I, Hardigan PC. Pharmacists' earnings determination: are part-time practitioners homogeneous in their response? J Pharm Health Serv Res. 2017;8(1):13-21.

23. Simoens S. Health economics of market access for biopharmaceuticals and biosimilars. J Med Econ. 2009;12(3):211-8.

24. Cowell F. Measuring inequality. Oxford: Oxford University Press; 2011.

25. Kawachi I, Kennedy BP. The relationship of income inequality to mortality: does the choice of indicator matter? Soc Sci Med. 1997;45(7):1121-7.

26. Palazuelos Manso E. The influence of earnings on income distribution in the United States. J Socio Econ. 2006;35(4):710-801.

27. Ross NA, Dorling D, Dunn JR, Henriksson G, Glover J, Lynch J, et al. Metropolitan income inequality and working-age mortality: a cross-sectional analysis using comparable data from five countries. J Urban Health. 2005;82(1):101-10.

28. Franzini L, Ribble J, Spears W. The effects of income inequality and income level on mortality vary by population size in Texas counties. J Health Soc Behav. 2001;42(4):373-87.

29. Campano F, Salvatore D. Income distribution. Oxford: Oxford University Press; 2006.

30. De Maio FG. Income inequality measures. J Epidemiol Community Health. 2007;61(10):849-52.

31. Shkolnikov VM, Andreev EM, Begun A. Gini coefficient as a life table function: computation from discrete data, decomposition of differences and empirical examples. Demogr Res. 2003;8(11):305-58.

32. Carvajal MJ, Popovici I, Hardigan PC. Pockets of inequality in the distribution of pharmacists' wages and salaries: a gender comparison. Innov Pharm. 2019. https://doi.org/10.24926/iip.v10i1.1393.

33. Alvaredo F. A note on the relationship between top income shares and the Gini coefficient. Econ Lett. 2011;110(3):274-7.

34. Murphy SM, Friesner DL, Scott DM. Do in-kind benefits influence pharmacists' labor supply decisions? J Reg Anal Policy. 2011;41(1):33.

35. Quiñones AC, Pullin RF. Reexamining shift work pharmacists in Illinois. Res Social Adm Pharm. 2011;7(4):444-50.

36. Polgreen LA, Mott DA, Doucette WR. An examination of pharmacists' labor supply and wages. Res Social Adm Pharm. 2011;7(4):406-14.

37. Dale-Olsen H, Østbakken KM. Økende $1 \varnothing n n s u l i k h e t ~ i$ Norge i perioden 2002-2012? Søkelys på arbeidslivet. 2016;33(01-02):122-41. 